\title{
Petrography, geochemistry and magnetic susceptibility of the Isortoq Fe-Ti-V deposit, Isortoq Giant Dykes, South Greenland
}

\author{
Diogo Rosa*, Alessandro Sandrin, Troels F.D. Nielsen, Høgni Vesturklett
}

Department of Petrology and Economic Geology, Geological Survey of Denmark and Greenland (GEUS), Copenhagen, Denmark

\begin{abstract}
The Isortoq Giant Dykes in the Proterozoic Gardar Province, South Greenland, include the Isortoq South giant dyke and the Isortoq North giant dyke. The fine-grained Fe-Ti-V deposit hosted by the Isortoq South giant dyke, referred to as the Isortoq Fe-Ti-V deposit, is considered a good test site for the use of magnetic susceptibility for the mapping of ore grades. Here, we test this and show that the $\mathrm{Fe}, \mathrm{Ti}$ and $\mathrm{V}$ distribution is controlled by titanomagnetite disseminated throughout fine-grained troctolite. The deposit displays a clear correlation between magnetic susceptibility and $\mathrm{Fe}, \mathrm{Ti}$ and $V$ grades in bulk samples of consecutive $2 \mathrm{~m}$ sections from 11 drill cores, totalling $2671 \mathrm{~m}$ in length. We observe that $\mathrm{Fe}, \mathrm{Ti}$ and $\mathrm{V}$ are almost entirely hosted in titanomagnetite, which controls the magnetic susceptibility. Field measurements of the magnetic susceptibility can thus be considered as a reliable exploration tool for this type of mineralisation. We further consider the origins of the deposit by reconnaissance petrography, mineral and bulk rock chemistry of the large mass of aphanitic Fe-rich troctolite in the Isortoq South giant dyke. We suggest that the deposit may represent the base of a basanitic to trachybasaltic magma chamber, in which Fe-rich immiscible melts accumulated, crystallised and fractionated. The processes suggested here may apply to other giant dykes and intrusions of the Gardar Province.
\end{abstract}

\section{Introduction}

The Isortoq iron-titanium-vanadium (Fe-Ti-V) deposit is located within the Isortoq Giant Dykes system $\left(60.96^{\circ} \mathrm{N}, 47.43^{\circ} \mathrm{W}\right.$; Fig. 1) in the Proterozoic Gardar Province, South Greenland (Upton 2013). The deposit is estimated to hold a resource of 70 million tonnes with an average of $29.6 \% \mathrm{Fe}, 10.9 \%$ $\mathrm{TiO}_{2}$, and $0.144 \% \mathrm{~V}_{2} \mathrm{O}_{5}$, at a cut-off of $15 \% \mathrm{Fe}$ (Turner \& Nicholls 2013). These metals are used by the steel, pigment and battery industries; and thus, the Isortoq Fe-Ti-V deposit is of interest to exploration companies. And yet its petrophysical parameters, needed for the inversion of magnetic surveys, are poorly understood, and the origin of the deposit remains unclear.
*Correspondence: dro@geus.dk

Received: 10 Mar 2020

Accepted: 06 May 2020

Published: 21 Aug 2020

Keywords: Isortoq Fe-Ti-V deposit, Gardar Province, petrophysics, magma chamber, troctolite

Abbreviations:

MS: magnetic susceptibility

OGDC: Older Giant Dyke Complex YGDC: Younger Giant Dyke Complex EMP: electron microprobe

TAS: Total Alkalis Silica

GEUS Bulletin is an open access, peerreviewed journal published by the Geological Survey of Denmark and Greenland (GEUS). This article is distributed under a CC-BY 4.0 licence, permitting free redistribution, and reproduction for any purpose, even commercial, provided proper citation of the original work. Author(s) retain copyright.

Edited by: Mette Olivarius (GEUS Denmark)

Reviewed by: Tod Waight (University of Copenhagen, Denmark) and Claire Nichols (Massachusetts Institute of Technology, USA)

Funding: See page 8

Competing interests: None declared

Additional files: See page 8 


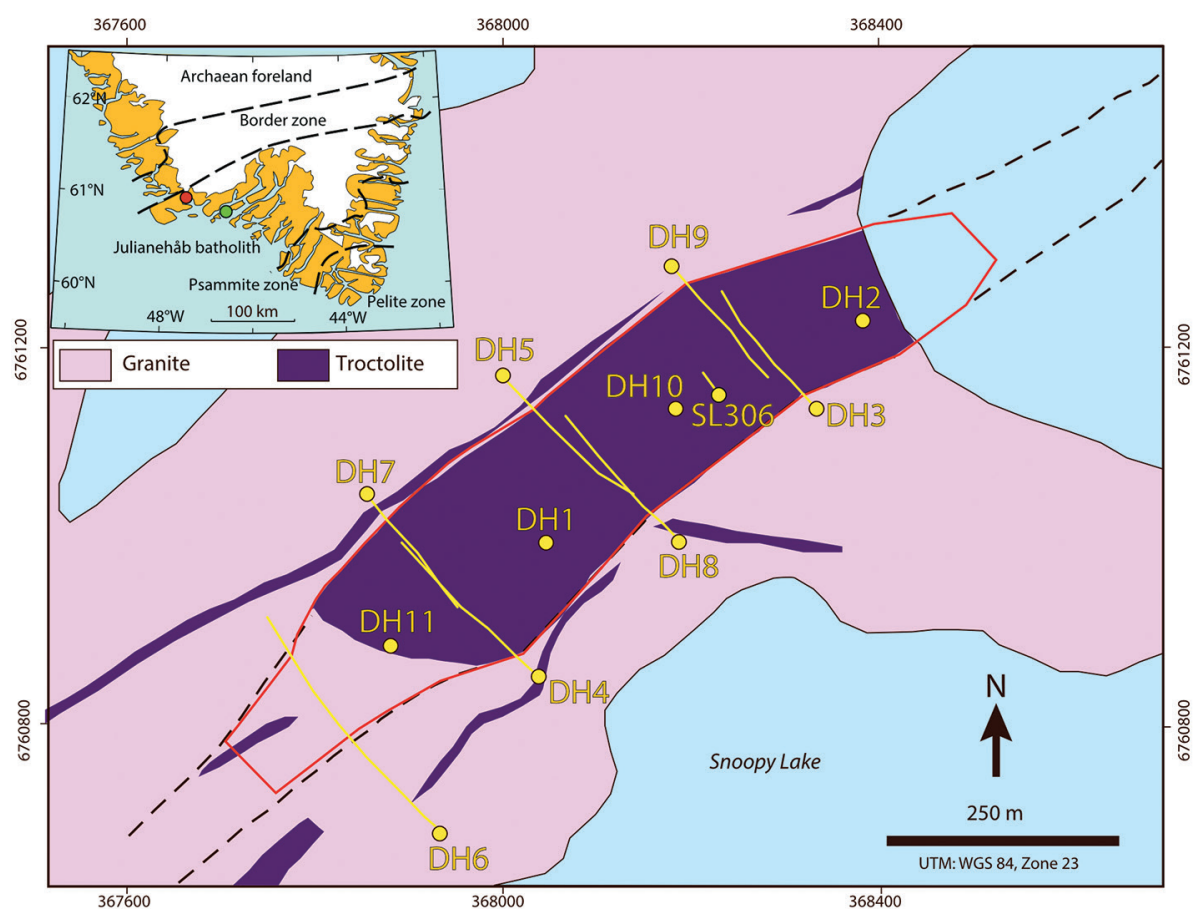

Fig. 1 Geological map of Isortoq South giant dyke, South Greenland. Yellow circles: location of drill cores. Yellow lines: projection to surface (for non-vertical drill holes) for the 12 studied drill cores. Black dashed lines: dyke extension. Solid red line: extent of mineral resource established by Turner \& Nicholls (2013). Inset map: includes the divisions of the Ketilidian orogen of Chadwick \& Garde (1996). Red circle: Location of the study area. Green circle: Tuttutooq.
The ore is a very fine-grained troctolite with high concentrations of disseminated FeTi-oxides in a dykelike intrusive body that is up to $200 \mathrm{~m}$ wide, $230 \mathrm{~m}$ deep and $>6 \mathrm{~km}$ long. The troctolite has no clear cumulus textures and is considered unusual because the grains are too small to sink in the magma. Therefore, the high Fe in the deposit cannot be because of the accumulation of titanomagnetite. If the high content of Fe-Ti-V is not because of the accumulation of titanomagnetite, then high Fe-Ti-V must be because of the accumulation of Fe-rich melt from which titanomagnetite crystallised.

Our investigation, therefore, has two aims: (1) to test the use of magnetic susceptibility (MS) for mapping of the deposit (Sandrin \& Elming 2006, 2007; Sandrin et al. 2009) and (2) to provide a hypothesis for the deposit's origin. The study is based on the data obtained from the diamond core during two drilling programmes of the Isortoq Fe-Ti-V deposit (Fig. 1), namely four samples for petrographic studies from core SL306 (drilled in 2005 by Hunter Minerals; Ferguson 2010) and 11 cores (DH1-11, drilled in 2012 by West Melville Metals Inc.; Ferguson 2013; Fig. 1), and MS data produced for this study.

A strong correlation between core lithology, chemistry and MS would validate MS as a reliable, fast and lowcost tool for field mapping of $\mathrm{Fe}, \mathrm{Ti}$ and $\mathrm{V}$ distribution elsewhere in the Isortoq Giant Dykes system and in the Gardar Province. It would also help to constrain areas that could be studied for grain size, morphology and mineralogy using the micro-beam instrumentation and provide important petrophysical parameters for inversion of magnetic surveys. In this study, we have systematically measured MS along a total of $2671 \mathrm{~m}$ in cores DH1-11 and correlated to the bulk compositions of a total of 1069 samples from the same drill cores (Ferguson 2013).

In addition, we include information on petrography, bulk rock and mineral chemistry from all 12 cores and present a conceptual model for the processes in the giant dyke that led to the accumulation of magnetite and, consequently, Fe, $\mathrm{Ti}$ and $\mathrm{V}$ enrichment. These insights constitute key parameters for exploration, evaluation and genesis of this deposit and potentially elsewhere in the Gardar Province.

\section{Geological setting}

The Isortoq Giant Dykes consist of (1) Isortoq South giant dyke and (2) Isortoq North giant dyke. These dykes were emplaced in older gneiss and granite of the Julianehåb Batholith of the Ketilidian Mobile Belt of South Greenland (Pulvertaft 2008). The giant dykes are part of the Middle Proterozoic Gardar rift and magmatic province comprising lavas, dyke swarms, intrusive complexes and the Older Giant Dyke Complex (OGDC) and Younger Giant Dyke Complex (YGDC) of the Tuttutooq area (Upton 2013). The Isortoq South giant dyke extends over a distance of $>6 \mathrm{~km}$, while the Isortoq North giant dyke can be traced for c. $8.5 \mathrm{~km}$ to the edge of the Greenland ice sheet. The 12 cores used in this study were drilled in the main body of the Isortoq South giant dyke, SW of Snoopy Lake (Fig. 1).

The large tabular intrusive bodies are referred to as giant dykes. However, all but one of the 12 cores drilled in the Isortoq South giant dyke exit into granitic host rock and show that Isortoq South is a tabular intrusive body with a floor contact at 100-200 m depth, 
dependent on collar elevation of the drill hole. The contact at the wall between the granitic host rocks and the Isortoq South giant dyke is composed of chilled basalt or fine-grained troctolite, whereas the contact at the floor is characterised by mingling with rheomorphic melts derived from the host rocks (core photos are provided in supplementary file SI 1).

\section{Samples and methods}

Core SL306 was drilled by Hunter Minerals in 2005. In 2006, four samples were provided to the Geological Survey of Denmark and Greenland (GEUS) for electron microprobe (EMP) analyses (see supplementary file S2). The main silicate, FeTi-oxides and rare sulphides were analysed for major and minor elements using a JEOL JXA-8200 Superprobe EMP at the Department of Geosciences and Natural Resource Management, University of Copenhagen, Geocenter, Denmark. The following elements were analysed $\left(\mathrm{SiO}_{2}, \mathrm{TiO}_{2}, \mathrm{Al}_{2} \mathrm{O}_{3^{\prime}}\right.$ $\mathrm{Cr}_{2} \mathrm{O}_{3}, \mathrm{~V}_{2} \mathrm{O}_{3}, \mathrm{FeO}, \mathrm{MnO}, \mathrm{NiO}, \mathrm{MgO}, \mathrm{CaO}, \mathrm{Na}_{2} \mathrm{O}, \mathrm{K}_{2} \mathrm{O}$ in silicates and FeTi-oxides, and $\mathrm{Mn}, \mathrm{S}, \mathrm{Cu}, \mathrm{Fe}, \mathrm{Ni}$ and $\mathrm{Co}$ in sulphides). Counting times were $20 \mathrm{~s}$ on peaks and $10 \mathrm{~s}$ on backgrounds, following standard procedures.
The acceleration voltage was $15 \mathrm{kV}$, and the beam current was $15 \mathrm{nA}$. Beam diameters were $5 \mu \mathrm{m}$. A combination of pure metal and mineral standards was used.

In 2011, West Melville Metals Inc. drilled 11 cores (DH1-11) for systematic assays, petrographic and geochemical studies. Grain size and whole-rock compositions for a total of 1069 samples were reported by Ferguson (2013). The data were provided for use here by Resource500 FeVTi - the present holder of the exploration licence. The core was split along its length and divided into $2 \mathrm{~m}$ sections. All material within each $2 \mathrm{~m}$ section was pooled for analysis. As such, each sample represents the average composition over each consecutive $2 \mathrm{~m}$ section of core, with no hiatuses in the sampling. Major elements $\left(\mathrm{SiO}_{2^{\prime}} \mathrm{Al}_{2} \mathrm{O}_{3^{\prime}} \mathrm{Fe}_{2} \mathrm{O}_{3}(\mathrm{~T}), \mathrm{MnO}\right.$, $\mathrm{MgO}, \mathrm{CaO}, \mathrm{Na}_{2} \mathrm{O}, \mathrm{K}_{2} \mathrm{O}, \mathrm{TiO}_{2}, \mathrm{P}_{2} \mathrm{O}_{5^{\prime}} \mathrm{Cr}_{2} \mathrm{O}_{3}$ and $\mathrm{V}_{2} \mathrm{O}_{5}$ ) were analysed by the fused puck XRF analysis. Methods are described in Ferguson (2013). As part of the original analytical work, trace elements ( $\mathrm{Ag}, \mathrm{Cd}, \mathrm{Cu}, \mathrm{Mn}, \mathrm{Mo}, \mathrm{Ni}, \mathrm{Pb}$, $\mathrm{Zn}, \mathrm{Be}, \mathrm{Bi}, \mathrm{Co}, \mathrm{Sr}$ and $\mathrm{Y}$ ) were analysed by four acid (near total) digestion followed by ICP-MS analysis at Actlabs, Canada. These data are available in Ferguson (2013), but are not discussed here.

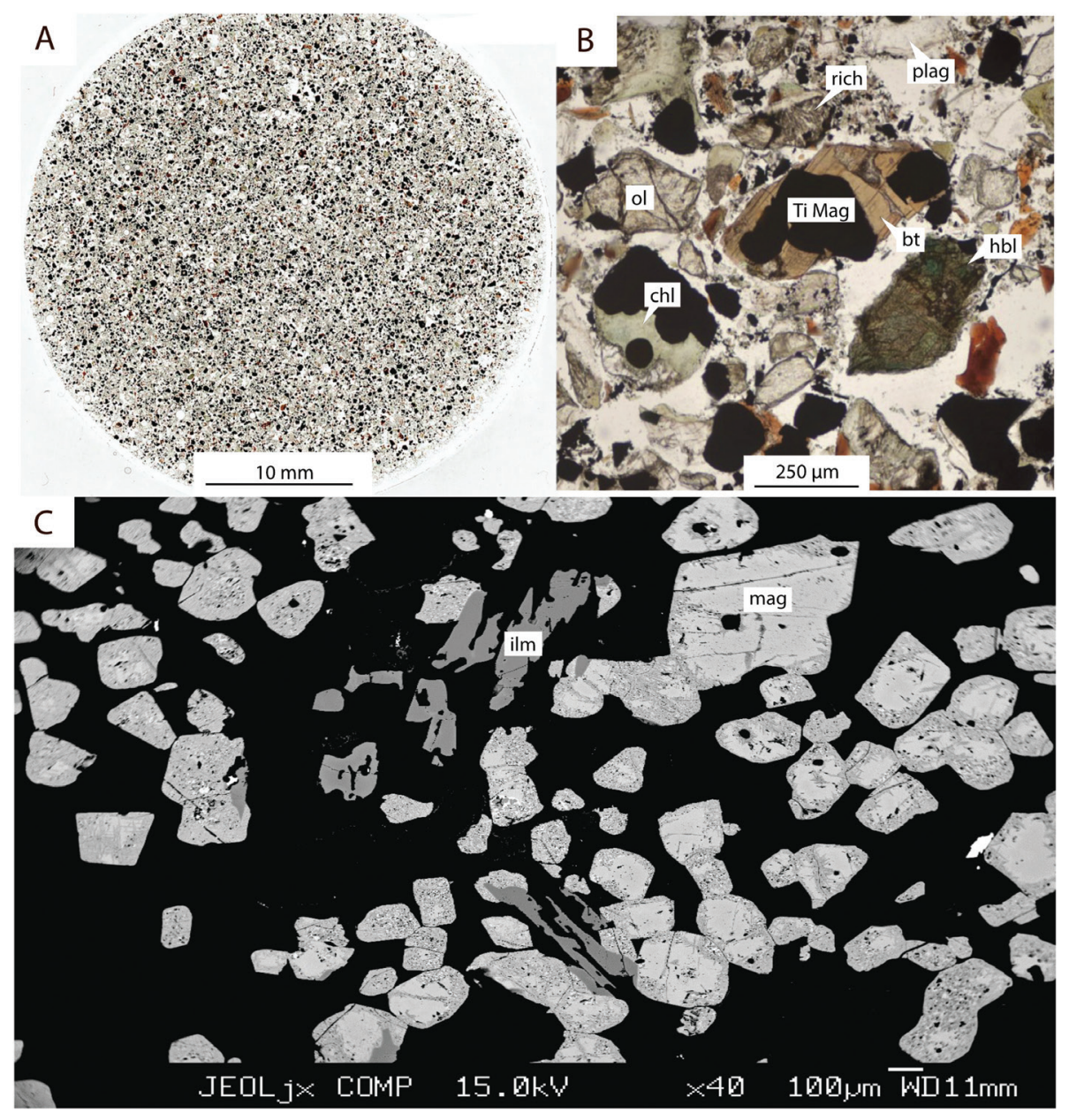

Fig. 2 Textural and mineralogical aspect of the troctolite. A: Cross section of drill core from $\mathrm{DH} 3$ (sample 12 DTQ003; depth c. 53 m). Photo courtesy of Resource 500 FeVTi Ltd). Note the fine-grained and featureless texture of the troctolite. B: Photomicrograph (transmitted light) of sample 12 DTQ003 in DH3 (depth c. $53 \mathrm{~m}$ ) showing olivine (ol), chlorite (chl), biotite (bt), plagioclase (plag), hornblende (hbl), titanomagnetite (Ti mag) and richterite amphibole (rich). Photo courtesy of Resource 500 FeVTi Ltd. Note the amphiboles partially replace clinopyroxene crystals. C: Backscatter image of sample from core SL 306 (depth c. $62 \mathrm{~m}$ ), showing magnetite (mag, light grey), ilmenite (ilm, grey) and other rock minerals such as pyroxene, olivine and plagioclase as dark to black. Note the fine-grained nature of the ore minerals. Small sulphide grains (white) are attached to titanomagnetite grains. 
We measured MS on cores DH1-11, using a KT-10 MS meter, jointly designed by Terraplus Inc (Canada) and Georadis S.R.O. (Czech Republic). This handheld instrument uses an oscillator with an inductive coil to measure the MS and can be easily used in the field as well as on rock samples in the laboratory. Drill cores DH1-11 all have a diameter of $3.65 \mathrm{~cm}$. Each MS reading represents a volume of core of $c .50 \mathrm{~cm}^{3}$.

\section{Results}

4.1 Petrography and mineral compositions (EMP) Petrographic characteristics for the Isortoq South troctolite are illustrated in Fig. 2 . The grain size of the troctolite as recorded in cores $\mathrm{DH} 1-11$ is $<500 \mu \mathrm{m}$ with an average of c. $200 \mu \mathrm{m}$. The troctolite is quite homogenous and aphanitic in texture, though we observed 1 to $10 \mathrm{~m}$ thick cyclic units of troctolite with felsic tops near the base of the body (see supplementary file SI 1). Mineral compositions for core SL306 are presented in supplementary file $\mathrm{SI}$ 2. The liquidus paragenesis includes olivine $\left(\mathrm{Fo}_{67-62}\right)$, clinopyroxene (magnesium number (mg\#) 70-75; where $\left.\mathrm{mg} \#=\mathrm{Mg} /\left(\mathrm{Mg}+\mathrm{Fe}^{2+}\right) \times 100\right)$ and titanomagnetite. The liquidus phases are enclosed in plagioclase (andesine: from $\mathrm{An}_{51}, \mathrm{Or}_{3}$ to $\mathrm{An}_{33}, \mathrm{Or}_{7}$ ), biotite and very minor accessory pyrrhotite and pentlandite (supplementary file SI 2). The troctolite was subjected to autometasomatism causing replacement of euhedral olivine by chlorite and magnetite. Hornblende and richterite replace parts of clinopyroxene crystals (Fig. 2b).

In SL 306, titanomagnetite with limited exsolution of ilmenite has 18-22 wt.\% $\mathrm{TiO}_{2}$ and 0.2-0.5 wt.\% $\mathrm{V}_{2} \mathrm{O}_{5}$, (Fig. 2c). Magnetite in titanomagnetite grains with significant volumes of exolved ilmenite has 2-8 wt.\% $\mathrm{TiO}_{2}$ and 0.6-0.8 wt.\% $\mathrm{V}_{2} \mathrm{O}_{5}$ (data in supplementary file $\mathrm{SI} 2$ ). The elevated concentrations of $\mathrm{V}_{2} \mathrm{O}_{5}$ in the latter grains reflect the partitioning of $\mathrm{V}$ to the reduced volume of magnetite that was left after exsolution of ilmenite.

\subsection{Bulk rock compositions (XRF)}

Major element data for all samples from drill cores DH111 are presented in Fig. 3 and Table $1 . \mathrm{SiO}_{2}$ is strongly negatively correlated with $\mathrm{TiO}_{2}$ and $\mathrm{FeO}$ * (*all $\mathrm{Fe}$ is
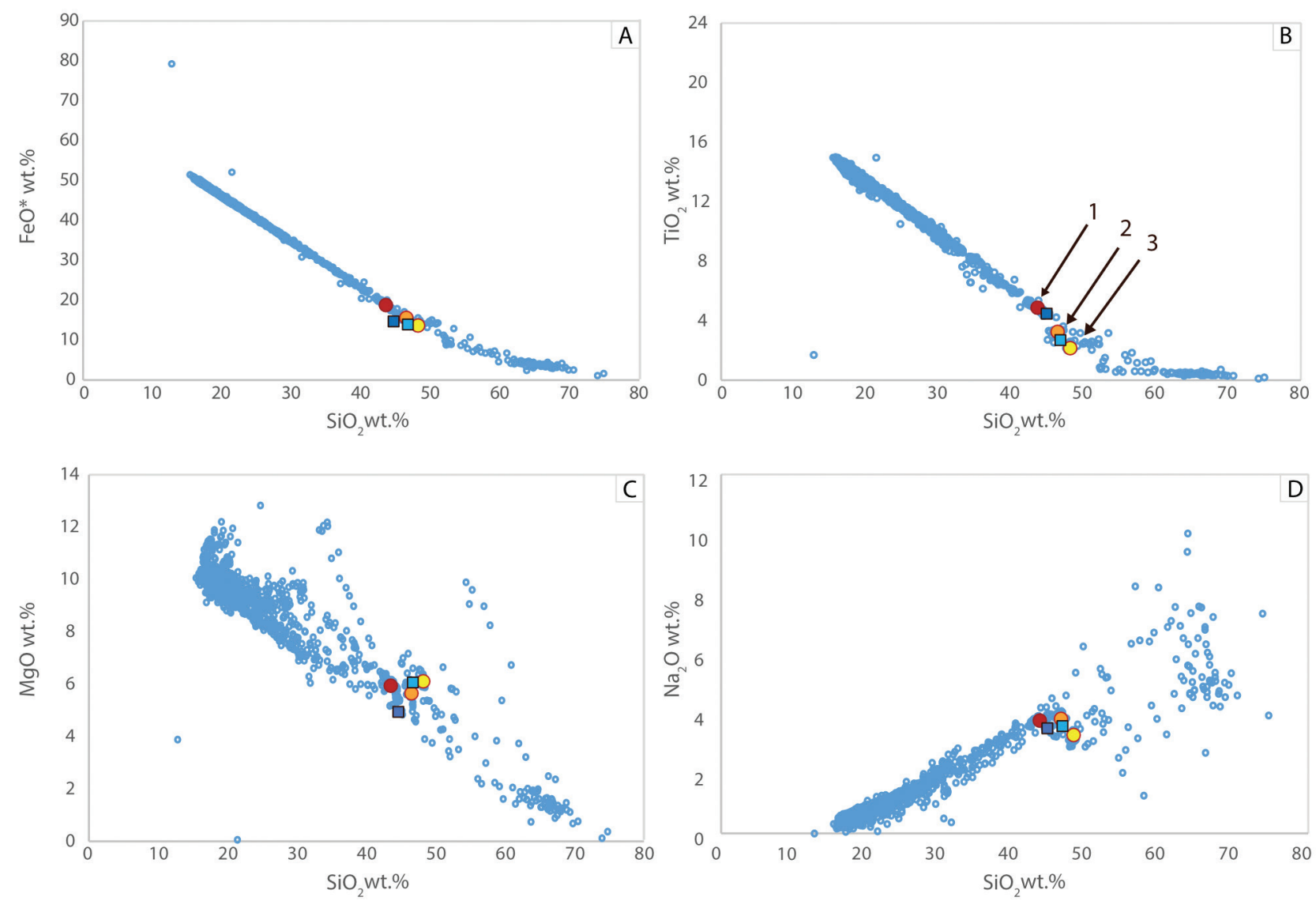

Fig. 3 Average bulk rock analyses for consecutive $2 \mathrm{~m}$ intervals of drill core in cores DH1-11. A: $\mathrm{SiO}_{2} \mathrm{vs} \mathrm{FeO}^{*}$. B: $\mathrm{SiO}_{2}$ vs $\mathrm{TiO}_{2}$. C: $\mathrm{SiO}_{2}$ vs $\mathrm{MgO}$. D: $\mathrm{SiO}_{2}$ vs $\mathrm{Na}_{2} \mathrm{O}$. A strong correlation exists between $\mathrm{SiO}_{2}$ and $\mathrm{TiO}_{2}, \mathrm{FeO}^{*}, \mathrm{MgO}$ and $\mathrm{Na}_{2} \mathrm{O}$. Note the control by composition at c. 16 wt.\% $\mathrm{SiO}_{2}$ and 50 wt.\% FeO*. Average compositions for composition groups 1, 2 and 3 (see Table 1) are shown. Red dot: Group 1, basanitic feeder, Isortoq South dyke. Orange dot: Group 2, trachybasalt. Yellow dot: Group 3, basalts. Dark blue square: average composition of basanitic chilled margins of Older Giant Dykes. Light blue square: average composition of trachybasaltic chilled margins of Younger Giant Dykes. 
reported as $\mathrm{FeO}$ ) and positively correlated with $\mathrm{Na}_{2} \mathrm{O}$ (Fig. 3). Correlations are strongest below 42 wt.\% $\mathrm{SiO}_{2}$. We identify three compositional clusters (groups 1, 2 and 3; Table 1 and Fig. 3) between 42 and 50 wt.\% $\mathrm{SiO}_{2}$.

Table 1 Average compositions for compositional groups 1, 2 and 3 of the Isortoq South giant dyke and the giant dykes of Tuttutooq

\begin{tabular}{|c|c|c|c|c|c|}
\hline & Group 1 & Chill & Group 2 & Chill & Group 3 \\
\hline & average $^{a}$ & $\mathrm{OGDC}^{\mathrm{b}}$ & average $^{c}$ & $Y_{G D C}^{d}$ & average $^{\mathrm{e}}$ \\
\hline & $\begin{array}{c}\text { Isortoq } \\
(\%)\end{array}$ & $\begin{array}{c}\text { Tuttutooq } \\
\text { (\%) }\end{array}$ & $\begin{array}{c}\text { Isortoq } \\
(\%)\end{array}$ & $\begin{array}{c}\text { Tuttutooq } \\
(\%)\end{array}$ & $\begin{array}{c}\text { Isortoq } \\
(\%)\end{array}$ \\
\hline $\mathrm{SiO}_{2}$ & 43.58 & 44.63 & 46.48 & 46.69 & 48.2 \\
\hline $\mathrm{TiO}_{2}$ & 4.79 & 4.52 & 3.27 & 2.67 & 2.19 \\
\hline $\mathrm{Al}_{2} \mathrm{O}_{3}$ & 13.48 & 16.07 & 15.48 & 16.96 & 16.51 \\
\hline $\mathrm{FeO}^{*}$ & 18.48 & 14.39 & 15.28 & 13.62 & 13.38 \\
\hline $\mathrm{MnO}$ & 0.25 & 0.2 & 0.21 & 0.19 & 0.19 \\
\hline $\mathrm{MgO}$ & 5.89 & 4.89 & 5.62 & 6.02 & 6.07 \\
\hline $\mathrm{CaO}$ & 6.49 & 7.91 & 7.69 & 7.9 & 8.42 \\
\hline $\mathrm{Na}_{2} \mathrm{O}$ & 3.79 & 3.54 & 3.84 & 3.6 & 3.31 \\
\hline $\mathrm{K}_{2} \mathrm{O}$ & 1.89 & 1.86 & 1.42 & 1.47 & 1.23 \\
\hline $\mathrm{P}_{2} \mathrm{O}_{5}$ & 1.36 & 2 & 0.72 & 0.87 & 0.49 \\
\hline sum & 100 & 100 & 100 & 100 & 100 \\
\hline
\end{tabular}

All Fe as FeO and classified according to Le Maitre et al. 2002 aBasanitic feeder (drill core DH10, 242.00 to 343.88 m; Ferguson 2013) bBasanitic chill of the Older Giant Dyke Complex (OGDC; Upton 2013) 'Trachybasalt average ( 45.85 to $47.20 \mathrm{wt} \% \mathrm{SiO}_{2}$; Fig. 5 in this paper; data in Ferguson 2013)

¿Trachybasaltic chill of Younger Giant Dyke Complex (Upton 2013) eTrachybasalt average (47.51 to $48.51 \mathrm{wt} \% \mathrm{SiO}_{2^{\prime}}$ see supplementary file SI 2 for this paper; data in Ferguson 2013)
$\mathrm{SiO}_{2}$ exceeds $50 \mathrm{wt} \%$ across the contact and into the host granites and gneisses of the Isortoq South giant dyke. All drill cores, except for $\mathrm{DH} 10$, penetrated the floor into a felsic basement. Drill core $\mathrm{DH} 10$ continued after a compositional break at c. $240 \mathrm{~m}$ from a troctolite with $>30$ wt.\% FeO* into basanite (Total Alkalis Silica [TAS] diagram, sensu Le Maitre et al. 2002) with < 20 wt.\% $\mathrm{FeO}^{*}$ and reached a depth of $344 \mathrm{~m}$. The basanitic composition (group 1) with <20 wt.\% FeO* from below the general elevation of the floor of the troctolite body is interpreted as the possible feeder for the magma in the Isortoq South giant dyke. The average composition of this feeder is comparable to the chilled margins of the OGDC at Tuttutooq (Upton 2013; Table 1), although it is somewhat more Fe-rich, which may be because of minor accumulation of titanomagnetite. Group 2 and 3 decrease in alkalinity to compositions similar to those of the YGDC of Tuttutooq (Upton 2013; Table 1) and have broadly comparable compositions of basaltic dykes in the Gardar Province (e.g. Bartels et al. 2015).

\subsection{Magnetic susceptibility}

MS measured in DH 11 is shown in Fig. 4. This drill core is presented here as the representative of all 11 drill cores (DH1-DH11) from the Isortoq South giant dyke (Diogo Rosa, unpublished data 2019). Also shown are the lithological variations between troctolite and granitic host rocks, as reported by West Melville Metals Inc.
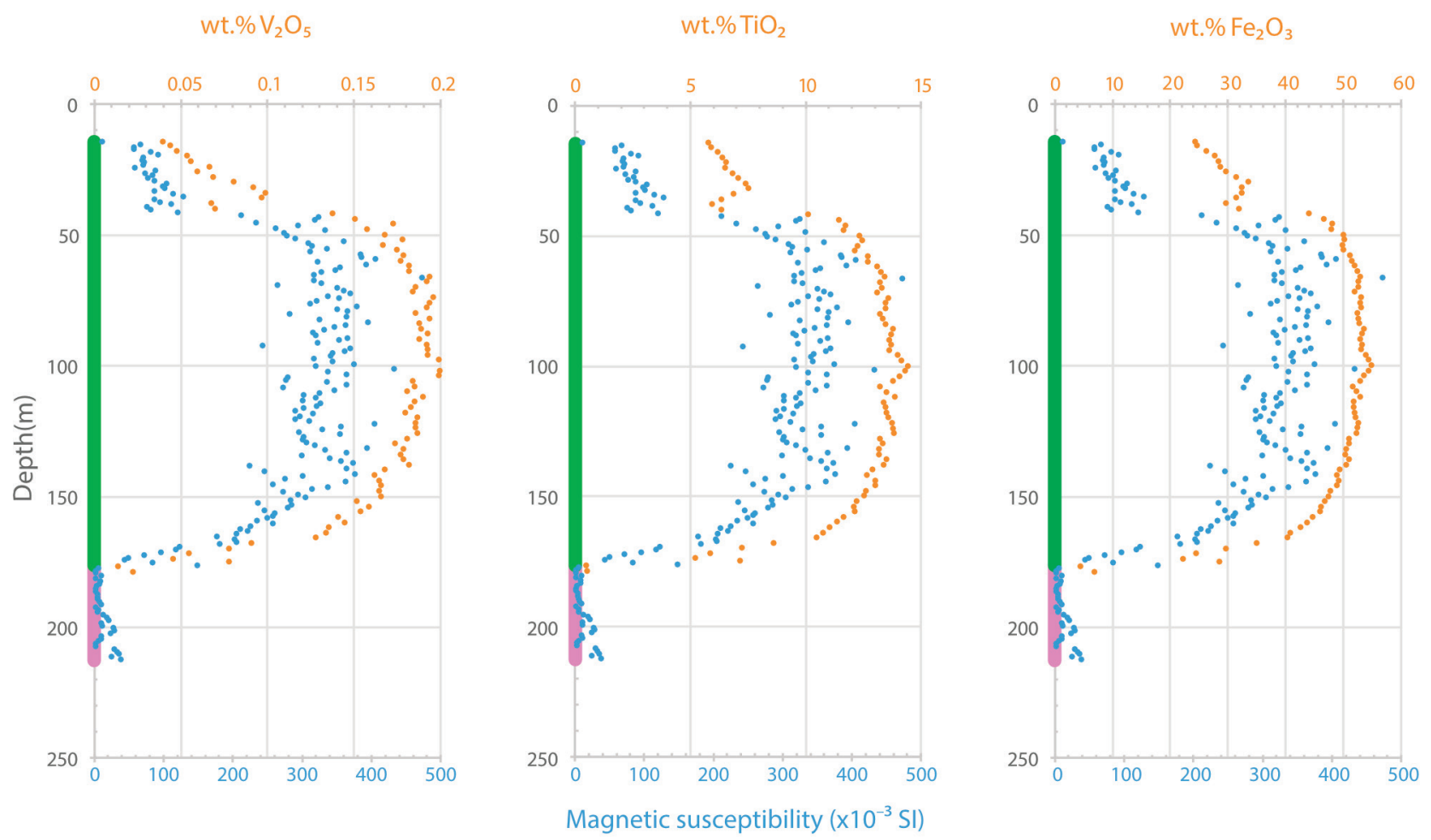

Fig. 4 Magnetic susceptibility (blue dots) and $\mathrm{Fe}_{2} \mathrm{O}_{3^{\prime}}, \mathrm{TiO}_{2}$ and $\mathrm{V}_{2} \mathrm{O}_{5}$ grades (orange dots) vs. drill depth in core $\mathrm{DH} 11$. Vertical green bar: Troctolite. Vertical pink bar: host granitic rock. 

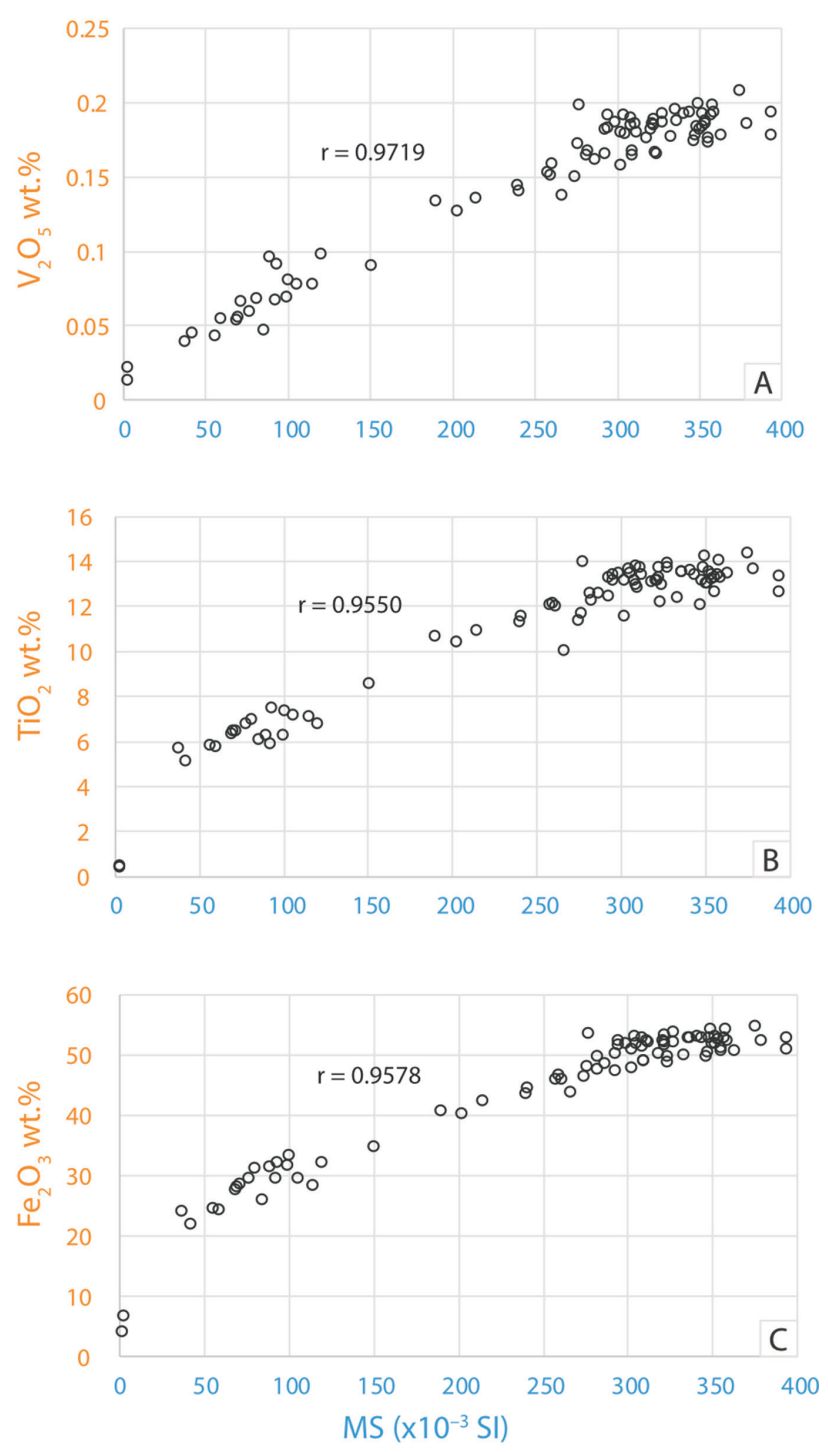

Fig. 5 Correlations between magnetic susceptibility (MS) and bulk rock compositions in core $\mathrm{DH} 11$. $\mathbf{A}$ : MS vs. $\mathrm{V}_{2} \mathrm{O}_{5}$, B: MS vs. $\mathrm{TiO}_{2}$. C: MS vs. $\mathrm{Fe}_{2} \mathrm{O}_{3}$.

(Ferguson 2013), and the $2 \mathrm{~m}$ bulk rock averages for $\mathrm{Fe}_{2} \mathrm{O}_{3}, \mathrm{TiO}_{2}$ and $\mathrm{V}_{2} \mathrm{O}_{5}$ (Ferguson 2013).

MS readings were taken at $1 \mathrm{~m}$ intervals, whereas the geochemical data are average compositions for consecutive $2 \mathrm{~m}$ intervals along the core. Thus, MS data were averaged (every two to three MS readings) to match the sampling of the geochemistry data. We correlate MS with concentrations of each of the three oxides $\left(\mathrm{Fe}_{2} \mathrm{O}_{3}, \mathrm{TiO}_{2}\right.$ and $\mathrm{V}_{2} \mathrm{O}_{5}$ ), as well as between the oxides themselves. Correlations between MS and the three oxides are very high ( $r=0.96-0.97)$, as are the correlations between the oxides ( $r=0.98-0.99$; Fig. 5).

\section{Discussion}

\subsection{The nature of the occurrence}

The Isortoq Fe-Ti-V deposit was previously suggested to represent a down-faulted block of a lopolithic intrusion
(Ferguson 2010), in which the mineralisation formed by classic accumulation of titanomagnetite. However, the chilled margins of the deposit, the mingling with melted country rock, and the cyclic development in the floor all suggest the deposit is an intrusive body formed in a magma chamber bound by faults of the Gardar graben system. The presence of a floor in 10 out of 11 drill cores and the occurrence of a possible feeder with a composition comparable to that of the OGDC at Tuttutooq (Table 1) in the deepest parts of $\mathrm{DH} 10$ supports that the occurrence represents the lower most part of an elongated dyke-like magma chamber.

\subsection{MS as exploration tool}

The MS investigation was initiated to test the use of MS as an exploration tool for the Isortoq-type deposit. The MS of a rock is controlled by the type and modal proportion of the rock-forming minerals. Often this control is exerted by the presence of relatively small quantities of ferromagnetic minerals, for example, magnetite, pyrrhotite (Hrouda et al. 2009; Sandrin et al. 2009). The logs in Fig. 4 show that the troctolite intervals with the highest $\mathrm{Fe}_{2} \mathrm{O}_{3}$ have one to two orders of magnitude higher MS values (0.3-0.4 International System of Units (SI) than those measured for granitic specimens. MS is strongly correlated with $\mathrm{Fe}_{2} \mathrm{O}_{3}(r=0.9578), \mathrm{TiO}_{2}(r=0.9550)$ and $\mathrm{V}_{2} \mathrm{O}_{5}(r=0.9719$; Fig. 5$)$ in the central part of the deposit and confirms that MS is a valid exploration tool (Caira 2012; Ferguson 2013; Turner \& Nicholls 2013). For most of the drill cores (Diogo Rosa, unpublished data 2019), inflexion points at MS values of approximately $0.05 \mathrm{SI}$ define the transition from granite to troctolite and mark a change in regression slopes (Fig. 5).

\subsection{Towards a petrogenetic model for the Isortoq Fe-Ti-V deposit}

The bulk rock analyses available in exploration reports give average compositions for consecutive $2 \mathrm{~m}$ intervals of drill core. The analysed bulk samples may, therefore, include granophyric veins or overlap with the host rock. A detailed account of the geochemistry and genesis of the deposit is, therefore, not possible without re-sampling. Throughout the main body, the bulk rock compositions are controlled by the proportions of basanitic to trachybasaltic melt components, diluted by a Fe-rich component with c. 16 wt. $\% \mathrm{SiO}_{2}, 15$ wt. \% $\mathrm{TiO}_{2}, 50$ wt.\% FeO* and 10 wt.\% $\mathrm{MgO}$ (Fig. 3). Scatter in $\mathrm{SiO}_{2}$ versus $\mathrm{MgO}$ (Fig. 3) probably reflects minor variations in the titanomagnetite to olivine plus clinopyroxene ratios in the analysed samples and minor mineral settling within the troctolite. The basanitic composition (Group 1 in Table 1) and the Fe-rich, thick cyclic units with felsic tops at the floor, suggest internal fractionation in semi-isolated 


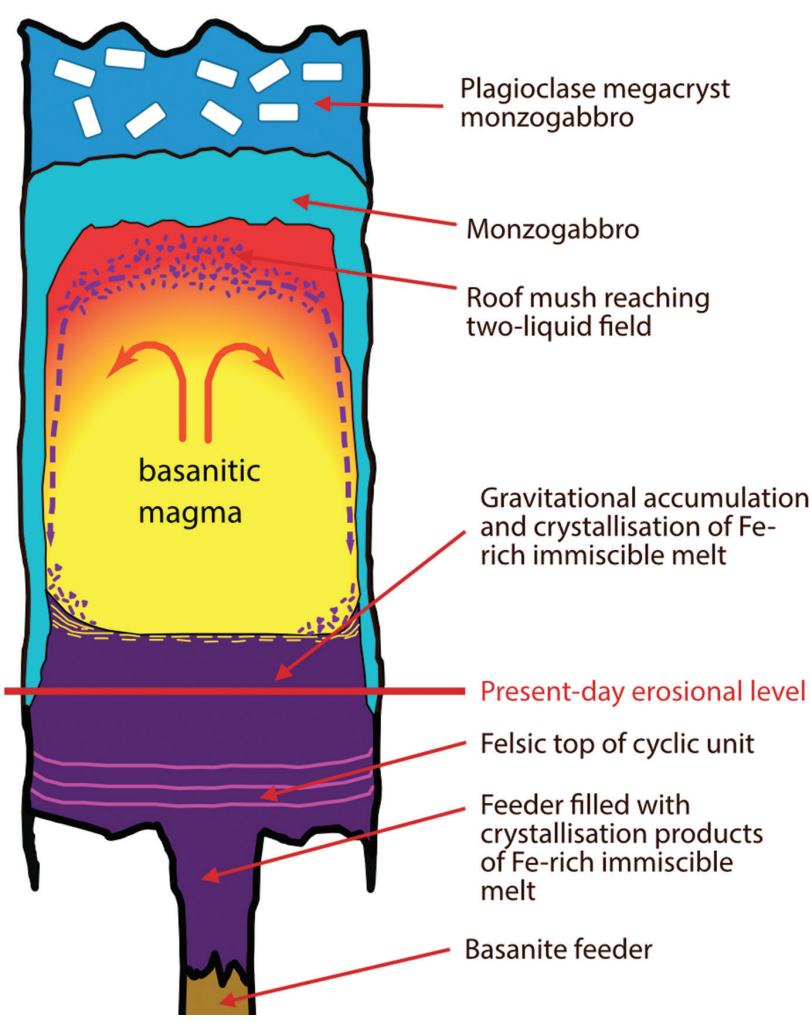

Fig. 6 Conceptual model for the formation of the Isortoq South giant dyke. Basanitic melt was emplaced in a magma chamber controlled by faults of the Gardar graben and a floor of granitic host rocks. Crystallisation and fractionation under the roof of the magma chamber resulted in floatation of feldspar crystals and evolution of the mush magma to the two-liquid field between Fe- and Si-rich silicate melts. Dense Fe-rich melts were continuously segregated and sank to the floor of the magma chamber where they crystallised and fractionated.

stratigraphic intervals. The combination of the finegrained texture and the absence of clear cumulative textures caused by gravitational sorting, and the formation of layers of titanomagnetite and olivine suggest that the Fe-rich rocks of the Isortoq South have crystallised in situ from dense and ponded Fe-rich melt.

Upton (2013), building on Bridgwater (1967), developed models for the magma chambers of the Gardar Province. Upton proposed a model that includes crystallisation, fractionation and floatation of plagioclase under the roof of the emplaced magma, as well as ponding of dense crystal mushes in giant dykes. In addition to these processes, we suggest that magma in the top of the magma chamber evolved to trachyandesitic compositions and reached the two-liquid field between coexisting Fe-rich and Si-rich melts (Charlier \& Grove 2012). As such, we suggest a preliminary conceptual model for the origin of the Isortoq Fe-Ti-V deposit (Fig. 6). The most evolved trachyandesitic dyke compositions of the Gardar region straddle the boundary to the immiscibility field (supplementary file SI 3). Fe-rich and dense immiscible melts segregated in a continuum and sank along the walls to the floor. In the Isortoq South giant dyke we only the see the base of the magma chamber in which the Fe-rich immiscible melts accumulated, crystallised and fractionated (Fig. 6). This preliminary model is reminiscent of processes recently suggested for the Skaergaard intrusion (Nielsen et al. 2020).

\section{Conclusions}

Strong correlations between MS and Fe, Ti and V concentrations confirm that MS is a valid tool for field mapping of the Fe, $\mathrm{Ti}$ and $\mathrm{V}$ distribution in the Isortoq Giant Dykes system. Further, the Fe-Ti-V mineralisation in the dyke is seen as the result of ponding and in situ crystallisation of immiscible Fe-rich silicate melt. The immiscible melt formed when basanitic to trachybasaltic melts common to the Gardar Province fractionated and reached the two-liquid field between Fe-rich and Si-rich melts.

\section{Acknowledgments}

The authors would like to thank Resource500 FeVTi for allowing the publication of some of the results included in a confidential report. They also like to acknowledge Nima Azad for assisting with the MS readings. Finally, this article benefited from the insights and discussions with Stefan Bernstein, Thomas Find Kokfelt and Jakob Keiding (GEUS).

\section{Additional information}

Funding statement

Part of this work was financed by Resource500 FeVTi as part of a study of the magnetic susceptibility of the diamond core drilled by West Melville Metals Inc.

Author contributions

DR: study coordination, exploration of the whole rock geochemistry data and its relationship with the MS, assessment of suitability of using MS for establishing grades. AS: interpretation of the MS results. TFDN: carried out EMP analysis and petrographic study, developed the petrogenetic model proposal. HV: performed MS readings on drill core.

\section{Additional files}

Three supplementary files are available alongside the article at $h t t p s: / /$ doi.org/10.34194/geusb.v44.4626

\section{References}

Bartels, A., Nielsen, T.F.D., Lee, S.R. \& Upton, B. 2015: Petrological and geochemical characteristics of Mesoproterozoic dyke swarms in the Gardar Province, South Greenland: evidence for a major sub-continental lithospheric mantle component in the generation of the magmas. Mineralogical Magazine 79(4), 909-939. https://doi.org/10.1180/ minmag.2015.079.4.04

Bridgwater, D. 1967: Feldspathic inclusions in the Gardar igneous rocks of South Greenland and their relevance to the formation of major anorthosites in the Canadian Shield. Canadian Journal of Earth Sciences 4, 995-1014. https://doi.org/10.1139/e67-068

Caira, N. 2012: NI43-101 Technical report on the Iron-Titanium-Vanadium potential of the Isortoq property, South Greenland, a territory of Denmark. Prepared by Argonaut Gold Odysseys Inc. on behalf of 
West Melville Metals Inc., 88 pp. http://www.aimva.com.au/LiteratureRetrieve.aspx?ID=185310

Chadwick, B. \& Garde, A.A. 1996: Palaeoproterozoic oblique plate convergence in South Greenland: a re-appraisal of the Ketilidian orogen. In: Brewer, T.S. (ed): Precambrian crustal evolution in the North Atlantic region. Geological Society Special Publication (London) 112, 179-196. https://doi.org/10.1144/GSL.SP.1996.112.01.10

Charlier, B. \& Grove, T.L. 2012: Experiments on liquid immiscibility along tholeiitic liquid lines of descent. Contributions to Mineralogy and Petrology 164, 27-44. https://doi.org/10.1007/s00410012-0723-y

Ferguson, J. 2010: Report on Exploration Licence 2009/38 Kuutsiaq. Unpublished report, Hunter Minerals Pty Ltd., 36 pp. https://data.geus. dk/gg_detail/?cat=rap\&id=86591

Ferguson, J. 2013: Isortoq project geological report - 2012. Unpublished report, Hunter Minerals Pty Ltd., 153 pp. https://data.geus.dk/ gg_detail/?cat=rap\&id=89801

Hrouda, F., Chlupacova, M. \& Chadima, M. 2009: The use of magnetic susceptibility of rocks in geological exploration (case histories study), a Terraplus report. https://www.geomatrix.co.uk/cms/resources/downloads/the-use-of-magnetic-susceptibility-of-rocks-in-geological-exploration-v1-1.pdf

Le Maitre, R.W. (ed.) et al. 2002: Igneous rocks: a classification and glossary of terms. Recommendations of the International Union of Geological Sciences Subcommission of the Systematics of Igneous Rocks. 236 pp. Cambridge University Press. https://doi.org/10.1017/ CB09780511535581

Nielsen, T.F.D., Rudashevsky, N.S., Rudashevsky, V.N., Weatherley, S.M. \& Andersen, J.C. Ø. 2020: Elemental distributions and mineral parageneses of the Skaergaard PGE-Au Mineralization: consequences of accumulation, redistribution, and equilibration in an upwardmigrating mush zone. Journal of Petrology, 60, 1903-1934. https://doi. org/10.1093/petrology/egz057

Pulvertaft, T.C.R. 2008: Field relations, petrography and chronology of the component units of the western part of the Palaeoproterozoic Julianehåb batholith, South Greenland. Danmarks og Grønlands Geologiske Undersøgelse Rapport 2008/70, 55 pp.

Sandrin, A., Edfelt, Å., Waight, T.E., Berggren, R. \& Elming, S.-Å. 2009: Physical properties and petrologic description of rock samples from an IOCG mineralized area in the northern Fennoscandian Shield, Sweden. Journal Geochemical Exploration 103, 80-96. https://doi. org/10.1016/j.gexp/o.2009.07.002

Sandrin, A. \& Elming, S.-Å. 2006: Geophysical and petrophysical study of an iron oxide copper gold deposit in northern Sweden. Ore Geology Reviews 29, 1-18. https://doi.org/10.1016/j.oregeorev.2005.06.001 Sandrin, A. \& Elming, S.-Å. 2007: Physical properties of rocks from borehole TJ71305 and geophysical outline of the Tjårrojåkka Cu-prospect, northern Sweden. Ore Geology Reviews 30, 56-73. https://doi. org/10.1016/j.oregeorev.2006.02.002

Turner, A.J. \& Nicholls, S.J. 2013: NI43-101 Technical Report on an initial resource estimate for the Isortoq Fe-Ti-V project, Qaqortoq district, South Greenland. Prepared by APEX Geoscience Ltd. on behalf of West Melville Metals Inc., 125 pp. https://data.geus.dk/ gg_detail/?cat=rap\&id=93978

Upton, B.G.J. 2013: Tectono-magmatic evolution of the younger Gardar southern rift, South Greenland. Geological Survey of Denmark and Greenland Bulletin 29, 124 pp. https://doi.org/10.34194/geusb. v29.4692 